ANUARIo DE Estudios MEdiEVAles

45/1, enero-junio de 2015, pp. 195-231

ISSN 0066-5061

doi:10.3989/aem.2015.45.1.07

\title{
ENTRE L'AMOR I EL DRET: L'ÚS DEL LÈXIC FEUDAL A LA LÍRICA AMOROSA MEDIEVAL CATALANA I VALENCIANA ${ }^{1}$
}

\author{
BETWEEN LOVE AND LAW: \\ FEUDAL VOCABULARY IN MEDIEVAL CATALAN \\ AND VALENCIAN COURTLY LOVE LYRIC
}

MARION CODERCH
Durham University - IRCVM (UB)

Resum: L'ús del lèxic del dret feudal per part dels trobadors de les corts occitanes durant els segles XII i XIII és la característica més innovadora d'aquesta manifestació artística. Aquesta convenció es manté, amb nivells d'intensitat variables, en la producció dels poetes catalans i valencians dels segles XIV i XV, que recullen i reelaboren la tradició trobadoresca. L'objectiu d'aquest article és identificar tendències en l'ús del vocabulari feudal a la lírica d'aquests poetes i interpretar-les en el context històric corresponent. La selecció de certs elements de la tradició anterior per part dels poetes dels segles XIV i XV ens informa de les estratègies que aplicaven per adaptar la seva obra als gustos del públic de l'època. D'aquesta mane$\mathrm{ra}$, es determinen similituds $i$ diferències concretes entre la lírica dels trobadors i la dels poetes catalans i valencians. Aquest procés és un pas necessari per definir la identitat de la poesia catalana dels segles XIV i XV, que tradicionalment ha estat descrita dins dels termes d'una comparació desavantatjosa amb altres tradicions líriques anteriors i contemporànies.

\begin{abstract}
The use of feudal vocabulary is the most innovative feature of twelfth- and thirteenth-century Occitan troubadour love lyric. The Catalan and Valencian poets who continued and reworked this tradition over the fourteenth and fifteenth centuries preserved this convention with varying degrees of fidelity. The aim of this paper is to identify trends in the use of feudal vocabulary in the works of Catalan and Valencian poets, and to interpret these tendencies in the light of contemporary historic developments. The poets' choices in selecting materials from the previous tradition provide valuable information about their strategies of adaptation to the requirements of their audiences. This analysis will allow delimitating similarities and differences between classical troubadour lyric and the works of later Catalan and Valencian poets, an essential step towards the definition of Catalan poetry in the late Middle Ages. The specific identity of this poetic expression has yet to be outlined, since it has traditionally been described in the context of disparaging comparisons with other earlier and contemporary poetic traditions.
\end{abstract}

\footnotetext{
${ }^{1}$ Abreviatures utilitzades: CICA $=$ Corpus Informatitzat del Català Antic; CODOLCAT = Corpus Documentale Latinum Cataloniae; RIALC = Repertorio Informatizzato dell'Antica Letteratura Catalana.
} 
Paraules clau: literatura medieval; lírica trobadoresca; lírica catalana medieval; feudalisme; lèxic.
Keywords: medieval literature; troubadour lyric; medieval Catalan lyric; feudalism; vocabulary.

\section{SUMARI}

1. Introducció.- 2. Pervivència del lèxic feudal a la lírica catalana i valenciana dels segles XIV i XV.- 2.1. Servir.- 2.2. Mercè.- 2.3. Senyora.- 2.4. Domna.- 2.5 . Poder.- 2.6. Franc, franca.- 2.7. Humil.- 2.8. Honor.- 2.9. Vassall.- 2.10. Obediència.2.11. Homenatge.- 2.12. Home.- 2.13. Baylia.- 2.14. Bauzia.- 3. Conclusions.- 4. Bibliografia citada.- Apèndix: relació de poetes d'obra consultada

\section{INTRODUCCIÓ}

L'ús de la metàfora feudal com a mirall de la relació entre l'amant i la dama és l'element més innovador i més característic de la lírica amorosa dels trobadors occitans. El llenguatge tècnic del feudalisme és omnipresent al llarg dels dos segles que abasta aquesta manifestació artística, i proporciona als trobadors i al seu públic un codi familiar per definir amb precisió la relació de poder i submissió que s'estableix entre els personatges de la ficció poètica. Les últimes tendències acadèmiques en la investigació sobre els orígens de la metàfora feudal s'inclinen a considerar-la com un mitjà de legitimació del discurs amorós dels trobadors en una època en què, arran de la reforma gregoriana, el desig sexual havia quedat estigmatitzat: equiparat a una necessitat fisiològica, com la gana o la set, es considerava pecaminós tant dins com fora del matrimoni. L'ús de la terminologia feudal per part dels trobadors representaria, als ulls de l'església, la voluntat d'acatar les normes socials predominants en el si d'una manifestació artística potencialment transgressora ${ }^{2}$. Així, doncs, l'ús de termes procedents del lèxic jurídic actuaria com a atenuant del possible impacte ideològic que el contingut de les cançons trobadoresques podia exercir en les autoritats eclesiàstiques.

Els poetes catalans i valencians que van continuar la tradició trobadoresca van adoptar, entre altres convencions, l'aplicació del lèxic feudal a la descripció de la casuística amorosa. Tenint en compte que l'entorn cultural de la Corona d'Aragó al final de l'Edat Mitjana és diferent de l'ambient en què va néixer la lírica dels trobadors, és lògic plantejar-se quin és el paper de la metàfora feudal en els segles XIV i XV: es tracta d'una convenció que els

\footnotetext{
${ }^{2}$ Reddy 2012, pp. 26-27.
} 
poetes reprodueixen irreflexivament, o hi podem detectar preferències que garanteixen la supervivència d'algunes paraules mentre en releguen d'altres a l'oblit? L'objectiu d'aquest article és identificar tendències en l'ús del vocabulari feudal a l'obra d'aquests poetes per començar a definir els trets característics de la seva lírica a la llum del context històric i social en què treballaven. Convencionalment, la poesia catalana i valenciana dels segles XIV i XV s'ha definit en relació amb altres tradicions anteriors i contemporànies: s'ha comparat amb la lírica trobadoresca clàssica, com és natural, però també amb la poesia en italià que es desenvolupava al mateix temps ${ }^{3}$. Creiem, però, que és hora d'orientar la comparació amb altres tradicions a la identificació dels trets particulars d'aquesta lírica, amb la finalitat d'establir, a llarg termini, un conjunt de característiques que en destaquin l'originalitat i la diferència ${ }^{4}$. L'estudi dels usos del lèxic feudal pretén, doncs, fer un pas endavant en aquest sentit. Amb aquesta intenció, oferim una selecció de 14 termes que apareixen a la lírica trobadoresca clàssica, ordenats en funció de la seva frequiència en la lírica dels poetes catalans i valencians. L'anàlisi de les tendències en l'ús d'aquests mots, basada en un grup de 688 poemes, no pretén ser exhaustiva ni establir conclusions definitives, però sí que és una primera mostra de les inquietuds artístiques dels nostres poetes, i esperem que serveixi, si més no, d'estímul per a l'elaboració d'estudis futurs en aquesta dirección ${ }^{5}$.

3 Aquest és el plantejament que proposen Riquer 1964, vol. I, p. 509; Vidal 1980, p. 130 i, més recentment, Terry 2003, p. 32 .

4 En aquesta línia, Cabré, Martí i Navàs reivindiquen la necessitat d'una nova perspectiva crítica en l'estudi de la lírica occitanocatalana del segle XIV, centrada, entre altres aspectes, en el context històric i en la varietat temàtica i formal de les obres conservades (2009, p. 353). Per la seva banda, Girolamo 2010, pp. 94-96, reivindica la necessitat de revisar les suposicions habituals sobre la manca d'originalitat de la lírica catalana tardomedieval.

5 Incloem a l'apartat corresponent a cada terme una taula que representa la proporció i la frequiència d'ús. Cal remarcar, però, que els percentatges sempre s'han de valorar en relació al nombre de testimonis existents: així, una proporció del $100 \%$ en l'ús d'un terme que només apareix en l'obra d'un poeta no n'implica, necessàriament, l'aparició freqüent. De la mateixa manera, cal tenir en compte la presència, en algunes èpoques, de poetes amb un nombre excepcionalment alt de textos conservats (com Ausiàs March o Joan Berenguer de Masdovelles), que pot fer variar els resultats globals. A l'Apèndix I oferim, a més, una relació dels poetes l'obra dels quals s'ha consultat. 


\section{PERVIVÈNCIA DEL LÈXIC FEUDAL A LA LÍRICA CATALANA I VALENCIANA DELS SEGLES XIV I XV}

\subsection{Servir}

\begin{tabular}{|c|c|c|}
\hline \multicolumn{3}{|r|}{ SERVIR } \\
\hline Èpoques & $\begin{array}{l}\text { Frequència } \\
\text { d'ús } \\
\text { (percentatge } \\
\text { de poemes en } \\
\text { què apareix) }\end{array}$ & Autors (nombre de poemes en què apareix/nombre total de poemes) \\
\hline $\begin{array}{l}\text { Primera meitat del } \\
\text { segle XIV }\end{array}$ & $31 \%$ & Joan de Castellnou (3/11), Tomàs Peris de Foces $(1 / 2)$ \\
\hline $\begin{array}{l}\text { Segona meitat del } \\
\text { segle XIV }\end{array}$ & $27 \%$ & Bernat de Palaol (1/2), Cançoneret de Ripoll (5/20) \\
\hline $\begin{array}{l}\text { Final del segle XIV- } \\
\text { inici del XV }\end{array}$ & $32 \%$ & Pau de Bellviure (1/1), Melcior de Gualbes (1/3), Jaume March (1/10), Gilabert de Próixita ( $8 / 20)$ \\
\hline $\begin{array}{l}\text { Primera meitat del } \\
\text { segle XV }\end{array}$ & $33 \%$ & $\begin{array}{l}\text { Jaume Bonet (1/2), Andreu Febrer (6/15), Gabriel Ferrús (1/6), Figueres (2/4), Lluís Icart (5/14), Arnau } \\
\text { March (2/6), Guillem de Masdovelles (3/15), Guerau de Massanet (1/1), A. de Muntanyans (1/1), Aznar } \\
\text { Pardo (1/2), Jordi de Sant Jordi (4/16) }\end{array}$ \\
\hline Mitjan segle XV & $13 \%$ & $\begin{array}{l}\text { Francesc Ferrer (2/10), Marti Garcia (2/11), Franci Guerau (4/7), Ausiàs March (8/128), Bernat Miquel } \\
(1 / 2) \text {, Pere Pou (1/1), Lluis de Requesens (1/9), Bernat Serra (1/1), Pere Torroella (6/29) }\end{array}$ \\
\hline $\begin{array}{l}\text { Segona meitat del } \\
\text { segle XV }\end{array}$ & $29 \%$ & $\begin{array}{l}\text { Joan Berenguer de Masdovelles (54/180), Romeu Llull (6/17), Joan Roís de Corella (1/17), Antoni } \\
\text { Vallmanya ( } 7 / 21)\end{array}$ \\
\hline
\end{tabular}

El terme servir i altres paraules derivades (servei, servidor, servent) van gaudir d'una popularitat remarcable a la poesia dels segles XIV i XV, amb un sentit que roman constant $\mathrm{i}$, pràcticament, inalterat en la seva vinculació a la descripció de la vivència amorosa. Eulalia Rodón Binué, en l'estudi que dedica al llenguatge tècnic del feudalisme a Catalunya durant el segle XI, defineix SERVITIUM com dependencia de un vasallo respecto a su señor i com obligaciones a las que está sujeto, afegint en una segona accepció prestación en virtud del vasallaje $e^{6}$. Els exemples de l'adaptació d'aquest sentit a la lírica amorosa són abundants a les cançons dels trobadors de l'època clàssica: Totz tems volrai sa onor e sos bes / e.lh serai um et amics e servire $(70,12$, vv. 22-23; Bernart de Ventadorn, Be m'an perdut lai enves Ventadorn); La nueyt (e tot iorn) cossir / co 'us pogues en grat servir (379, 2, vv. 33-35; Raimbaut d'Aurenga, Si ay perdut mon saber); Qu'ilh degues acolhir / de bo grat mo servir (242, 76, vv. 76-77; Guiraut de Bornelh, Sol c'Amor me plevis) ${ }^{7}$.

6 Rodón 1957, p. 235.

7 Les cites dels textos procedeixen de les edicions corresponents, recollides a la bibliografia final. Altres fonts de referència són Alfonsi 1986 i les bases de dades Corpus des Troubadours i RIALC, a les quals hem recorregut sempre que no ha estat possible accedir a les edicions impreses. 
De la mateixa manera que ho feien els seus antecessors, els poetes catalans i valencians empren el verb servir com a sinònim d'amar:

ab cor que no'm gir de servir vos, queu mir e desir dins mon cors ser e mayti;

Capellà de Bolquera, Ffis vos suy ayman ses engan, vv. 8-9

Qu'yeu am e cerff, e no fau res que folhs, de les milhors la millor, e suy seus;

Andreu Febrer, Combas e valhs, puigs, muntanyes e colhs, vv. 9-10

Del que volent vós servir no reposa, ço és, sens ventura espera la fi;

lo que és prest a vós servir,

lo nom no us fretura a dir, cos de què vós sou la vida.

Joan Roís de Corella, Una sou vós, lo remei de ma vida, vv. 6-10

La identificació entre amor i servei està consolidada fins al punt que es pot alterar el patró convencional, segons el qual el servidor se sol identificar amb el gènere masculí i, l'objecte del servei, amb el femení, per convertir la dama en servidora d'un altre home i designar, d'aquesta manera, la relació amorosa que existeix entre tots dos: Dona: vos sou d'altri çerventa (Joan Berenguer de Masdovelles, Amor tots jorns me presenta, v. 29).

El vigor d'aquest grup de paraules al llarg dels segles XIV i XV es va veure, en bona part, afavorit pel fet que permetia als poetes una certa variació lèxica dins del camp semàntic de l'amor, tan explotat a la lírica. Tanmateix, no s'ha de desestimar el fet que la identificació entre amor i servei no és original ni exclusiva de la lírica dels trobadors occitans, ja que apareix a la literatura hebrea i a la poesia grega i llatina, com afirmen Glynnis M. Cropp i Antonio Pichel ${ }^{8}$. L'antiguitat de l'ús del terme en aquest sentit ens en mostra l'arrelament profund en la tradició lírica amorosa occidental, i pot explicar l'èxit de què va gaudir al llarg d'una època en què, com veurem, altres paraules associades al món de les relacions feudals no gaudeixen de la mateixa sort.

8 Cropp 1975,p. 220; Pichel 1987, p. 60. 


\subsection{Mercè}

\begin{tabular}{|c|c|c|}
\hline \multicolumn{3}{|r|}{ MERCE் } \\
\hline Èpoques & $\begin{array}{l}\text { Frequència } \\
\text { d'ús } \\
\text { (percentatge } \\
\text { de poemes en } \\
\text { què apareix) }\end{array}$ & Autors (nombre de poemes en què apareix/nombre total de poemes) \\
\hline $\begin{array}{l}\text { Primera meitat del } \\
\text { segle XIV }\end{array}$ & $31 \%$ & Joan de Castellnou (3/11), Tomàs Peris de Foces $(1 / 2)$ \\
\hline Mitjan segle XIV & $67 \%$ & Joan Blanch (1/1), Llorenç Mallol (1/2) \\
\hline $\begin{array}{l}\text { Segona meitat del } \\
\text { segle XIV }\end{array}$ & $40 \%$ & Cançoneret de Ripoll (8/20) \\
\hline $\begin{array}{l}\text { Final del segle XIV- } \\
\text { inici del XV }\end{array}$ & $50 \%$ & Pau de Bellviure (1/1), Melcior de Gualbes (1/3), Jaume March (2/10), Gilabert de Próixita (13/20) \\
\hline $\begin{array}{l}\text { Primera meitat del } \\
\text { segle XV }\end{array}$ & $26 \%$ & $\begin{array}{l}\text { Joan Basset (3/20), Jaume Bonet (1/2), Andreu Febrer (8/15), Gabriel Ferrús (1/6), Figueres (1/4), Lluís } \\
\text { Icart (3/14), la reina de Mallorca (1/1), Arnau March (2/6), Guillem de Masdovelles (2/15), Joan } \\
\text { Olivella (1/1), Aznar Pardo (1/2), Francesc de la Via (1/4), Lluís de Vila-rasa (1/11) }\end{array}$ \\
\hline Mitjan segle XV & $11 \%$ & $\begin{array}{l}\text { Francesc Ferrer (3/10), Marti Garcia (5/11), Franci Guerau (2/7), Ausiàs March ( } 9 / 128) \text {, Pere Torroella } \\
(1 / 29)\end{array}$ \\
\hline $\begin{array}{l}\text { Segona meitat del } \\
\text { segle XV }\end{array}$ & $19 \%$ & Joan Berenguer de Masdovelles (35/180), Romeu Llull (2/17), Antoni Vallmanya (5/21) \\
\hline
\end{tabular}

Rodón Binué no inclou el terme en el seu registre de vocabulari tècnic del feudalisme, però el Corpus Documentale Latinum Cataloniae (CODOLCAT) recull un ús extensiu de MERCES a la documentació durant els segles X i XI. En la lírica dels trobadors, merce apareix com a sinònim de "pietat": Merces n'aiaz e chauzimen! (389, 1, v. 171; Raimbaut d'Aurenga, Donna, cel que us es bos amics); Aissi-us clam merce umilmens (242, 60, v. 51; Giraut de Bornelh, Can lo glatz e.lfrechs e la neus); Per que-l clam doussamen merce / Que $\cdot$ l prend pietat de me (167, 5, vv. 9-10; Gaucelm Faidit, Anc no cugei qu'en sa preizo), tot i que, en ocasions, també s'utilitza en el sentit més precís de "recompensa que l'amant espera obtenir": Et er merces s'ill me denh'aculhir (155, 5, v. 53; Folquet de Marselha, Ben an mort mi e lor); Mas si-m fezes amistat e pitansa, / No pogra far el mon major merce (364, 50, vv. 14-15; Peire Vidal, Una chanson ai faita mortamen); Per qu'er merces si m’amaz (392, 7, v. 10; Raimbaut de Vaqueiras, Domna, tant vos ai preiada).

Pel que fa a l'ús del terme en el territori lingüístic català, Joan Coromines constata la presència de mercè com a favor o pietat de la dona requerida envers el seu galant o enamorat, i afirma que aquest ús, juntament amb

9 Cropp 1975, p. 176; Pichel 1987, p. 93. 
d'altres que exemplifica, es manté amb lleus variacions al llarg dels segles posteriors al desenvolupament de la lírica trobadoresca ${ }^{10}$. Efectivament, el sentit de mercè com a sinònim de "pietat" es manté inalterat a la poesia dels segles XIV i XV:

Midons, de mi merce us prenya, que $m$ tenits en fort catiu,

Cançoneret de Ripoll, Midons qu'eu aym ses bausia; XVI, vv. 18-19

Si u digui may, qu'ap vos, dompna veraya, hon mis lo cor lo primer jorn que us viu, no trop merses, ans me fazats l'esquiu, havent plaser de tot mal ques eu haya; Llorenç Mallol, Molt[es] de vetz, dompna, $m$ suy presentat, vv. $25-28$

En lo meu coll veig penjar una mola, e lo gran fons on seré trabucat si doncs mercé no vol haver tallat la corda fort; mas coltell no esmola. Mercé deman ab veu espaordida, Ausiàs March, Sí col malalt que.l metge lo fa cert; LIX, vv. 17-21

Les variacions en l'ús del mot que trobem a la lírica dels poetes catalans i valencians tenen a veure, sobretot, amb el personatge de la ficció poètica que dispensa mercè. Així, l'amant satisfet de la seva fortuna celebra l'actitud favorable de la dama atorgant-li grat e merce (Joan de Castellnou, Dieus! E com soy alegres e joyos, v. 12), però aquell que té raons per criticar la dama no pot concedir-li prou mercè com per reprimir el maldir:

En tot maldich no gens en be, greu m'es lo dir [e]sta veguada, mas e'u de ffer, car ten horada sou, que no pusch aver merçe de vos, abans cove perlar Joan Berenguer de Masdovelles, Null temps cuydi, dona, trobar, vv. 5-9

Malgrat que la vigència del terme al llarg de l'època que ens ocupa és indiscutible, s'adverteix una certa davallada en la freqüència d'ús al llarg de la segona meitat del segle XV.

10 Coromines 1980-2001, vol. V, p. 602. 


\subsection{Senyora}

\begin{tabular}{|c|c|c|}
\hline \multicolumn{3}{|r|}{ SENYORA } \\
\hline Èpoques & $\begin{array}{l}\text { Frequència } \\
\text { d'ús } \\
\text { (percentatge } \\
\text { de poemes en } \\
\text { què apareix) }\end{array}$ & Autors (nombre de poemes en què apareix/nombre total de poemes) \\
\hline Mitjan segle XIV & $50 \%$ & Llorenç Mallol (1/2) \\
\hline $\begin{array}{l}\text { Segona meitat del } \\
\text { segle XIV }\end{array}$ & $5 \%$ & Cançoneret de Ripoll (1/20) \\
\hline $\begin{array}{l}\text { Final del segle XIV- } \\
\text { inici del XV }\end{array}$ & $100 \%$ & Melcior de Gualbes (3/3) \\
\hline $\begin{array}{l}\text { Primera meitat del } \\
\text { segle XV }\end{array}$ & $21 \%$ & $\begin{array}{l}\text { Joan Basset (4/20), Andreu Febrer (3/15), Gabriel Ferrús (1/6), Figueres (1/4), Lluís Icart (3/14), la } \\
\text { reina de Mallorca (1/1), Arnau March (2/6), Aznar Pardo (1/2), Jordi de Sant Jordi (1/16), Francesc de } \\
\text { la Via (1/4), Lluís de Vila-rasa (3/11) }\end{array}$ \\
\hline Mitjan segle XV & $10 \%$ & $\begin{array}{l}\text { Francesc Ferrer (1/10), Martí Garcia (2/11), Franci Guerau (4/7), Ausiàs March (4/128), Bernat Miquel } \\
(1 / 2) \text {, Pere Pou (1/1), Lluís de Requesens (1/9), Bernat Serra (1/1), Francesc Sunyer (1/5), Pere } \\
\text { Torroella }(4 / 29)\end{array}$ \\
\hline $\begin{array}{l}\text { Segona meitat del } \\
\text { segle XV }\end{array}$ & $21 \%$ & $\begin{array}{l}\text { Anònim BNMadrid, ms. } 3066 \text { (1/1), Joan Fogassot ( } 2 / 10) \text {, Joan Berenguer de Masdovelles (39/180), } \\
\text { Romeu Llull (4/17), Joan Rois de Corella (2/17), Antoni Vallmanya }(3 / 21)\end{array}$ \\
\hline
\end{tabular}

Senyora, senyorejar, senyoria, senyoriu, senyoril: l'ús d'aquests termes a la poesia amorosa de finals de l'Edat Mitjana és constant i abundant. En la documentació jurídica de l'entorn feudal, el tractament SENIOR és honorífic i representa un símbol de superioritat social, associat al domini de les terres $i$ vassalls que es troben sota la jurisdicció corresponent ${ }^{11}$. A la documentació feudal, el terme es troba, en ocasions, aplicat a l'esposa del gran propietari feudal ${ }^{12}$. Aquest ús va passar a la lírica dels trobadors, que, com és ben conegut, van emprar el terme, juntament amb midons, per designar la dama: De midonz fatz dompn'e seignor $(389,32$, v. 25; Raimbaut d'Aurenga, Non chant per auzel ni per flor); E fatz de vos ma domn'e mon senhor (364, 46, v. 89; Peire Vidal, Tant ai longament cercat); Qu'elh'es don'e senher / de mi ses totz pariers (392, 16, vv. 41-42; Raimbaut de Vaqueiras, Engles, un novel descort). Les teories sobre l'origen de l'ús del masculí midons aplicat a la dama varien: mentre alguns crítics consideren l'ús de la forma masculina un exemple de la influència directa de la poesia àrab, altres hi veuen una voluntat d'exalçar la sobirania de la dona i la submissió de l'amant establint un paral·lelisme amb el model

11 Rodón 1957, pp. 231-233.

12 Corral 1996, pp. 93-94. A propòsit de la lírica gallegoportuguesa, Corral destaca l'ús del terme senhor indistintament per al gènere masculí i per al femení; la forma analògica senhora apareix en casos particulars per exigències estilístiques. 
feudal convencional, en què, habitualment, la senyoria és exercida per un home ${ }^{13}$.

Durant el segle XIV i XV, la denominació senyor aplicada a la dama es deixa de banda. En els casos en què el terme apareix associat a la dama no es pot afirmar que aquesta hi sigui designada. Un exemple el trobem en els versos següents, on el context suggereix que l'ús d'aquesta forma respon a la intenció de subratllar expressament l'analogia amb la relació vassallàtica en termes generals, i no pas a la voluntat de constatar la submissió de l'amant a la dama:

E los atorch: mala dona procura perque de l'hom se deu ensenyorir; vos ests senyors eu servents, tal no quir, per ques a me l'avol tall no fa cura. Jordi de Sant Jordi, D'aver lo nom e lo dret tall d'aymia, vv. 37-40

En un dels escassos exemples de lírica amorosa catalana en veu femenina, la dona adopta l'ús convencional del terme senyora, segons el qual la dama rep el servei amorós de l'amant, i, més endavant, anomena senyors el seu amic, confirmant la identificació del terme en el context amorós amb el concepte de "persona estimada" o "persona desitjada", és a dir, persona a la qual l'amant se sotmet voluntàriament, independentment del gènere:

Ez yeu am tal qu'es bo e belh, e suy gaya co.l blanch oselh que, per amor, cria son chant, e suy senyora e capdelh, e ceylh qu'eu am[e] no's n'apelh; (...)

L'anyoramen e-l gran desir

qu'yeu ay per vos me cuyd'alcir, mon dols senyor e car;

La Reina de Mallorca, Ez yeu am tal qu'es bo e belh, vv. 1-5 i 14-16

Pel que fa a les tendències en l'ús d'aquests termes, s'adverteix un augment en la freqüència a partir de l'inici del segle XV. Com veurem en l'apartat següent, al llarg de la primera meitat del segle les paraules d'aquest conjunt conviuen i comparteixen popularitat amb domna, midons, i altres termes que s'empraven com a sinònims i que, durant aquests decennis, es troben encara en ple vigor.

13 Pichel 1987, p. 31; Alfonsi 1986, p. 166; Sánchez 1990, p. 134. Roncaglia 1992, pp. 1115-1116, atribueix a midons un valor honorífic, independent del gènere de la persona a qui faci referència, i desproveït de connotacions tècniques feudals. 


\subsection{Domna}

\begin{tabular}{|c|c|c|}
\hline \multicolumn{3}{|r|}{ DOMNA } \\
\hline Èpoques & $\begin{array}{l}\text { Frequència } \\
\text { d'ús } \\
\text { (percentatge } \\
\text { de poemes en } \\
\text { què apareix) }\end{array}$ & Autors (nombre de poemes en què apareix/nombre total de poemes) \\
\hline $\begin{array}{l}\text { Primera meitat del } \\
\text { segle XIV }\end{array}$ & $15 \%$ & Joan de Castellnou (1/11), Tomàs Peris de Foces (1/2) \\
\hline Mitjan segle XIV & $75 \%$ & Anònim Florència, ms. Palat 1052 (1/1), Joan Blanch (1/1), Llorenç Mallol (1/2) \\
\hline $\begin{array}{l}\text { Segona meitat del } \\
\text { segle XIV }\end{array}$ & $25 \%$ & Cançoneret de Ripoll (5/20) \\
\hline $\begin{array}{l}\text { Final del segle XIV- } \\
\text { inici del XV }\end{array}$ & $57 \%$ & Pau de Bellviure (1/1), Gilabert de Próixita (11/20) \\
\hline $\begin{array}{l}\text { Primera meitat del } \\
\text { segle XV }\end{array}$ & $24 \%$ & $\begin{array}{l}\text { Anònim VeAg (1/1), Joan Basset (3/20), Andreu Febrer (3/15), Lluís Icart (4/14), Ivany (1/2), Joseta } \\
(1 / 1) \text {, Guillem de Masdovelles (1/15), Guerau de Massanet (1/1), Aznar Pardo (1/2), Jordi de Sant Jordi } \\
(5 / 16)\end{array}$ \\
\hline Mitjan segle XV & $9 \%$ & Francesc Ferrer (1/10), Ausiàs March (1/128), Pere Joan de Masdovelles (1/6), Bernat Serra (1/1) \\
\hline $\begin{array}{l}\text { Segona meitat del } \\
\text { segle XV }\end{array}$ & $11 \%$ & Joan Berenguer de Masdovelles (20/180), Romeu Llull (1/17) \\
\hline
\end{tabular}

Rodón Binué constata l'ús honorífic de DOMINUS, DOMNUM, DON i de les formes femenines DOMINA, DOMNA ${ }^{14}$. L'ús de domna i midons a la lírica occitana és omnipresent, i sovint el terme domna va acompanyat d'epítets positius: Domna gent'et essernida, / Gai'e pros e conoissenz (392, 7, vv. 2930; Raimbaut de Vaqueiras, Domna, tant vos ai preiada); Franca dompn'e corteza (213, 5, v. 92; Guillem de Cabestanh, Li dous consire); Dona valens, humils et agradans (82, 3, v. 17; Bertran Carbonel, Aissi com sel qu'entrels pus assaians). Tanmateix, cal recordar que és a l'entorn d'aquest mot on es crea el personatge poètic de la mala domna, criticada amb graus variables de duresa per les seves accions: Si be·m partetz, mala domna, de vos, / non es razos q'ieu me parta de chan (194, 19, vv. 1-2; Gui d'Ussel, Si be·m partetz, mala domna, de vos).

Els poetes catalans i valencians continuen fent servir domna i midons al llarg dels segles XIV i XV, en bona mesura a la manera dels troba-

14 Rodón 1957, pp. 88-89. Bisson afirma que, fins al final del segle X, l'ús de DOMINUs havia estat reservat a Déu, al rei i als bisbes. Més tard es va estendre als comtes, per passar, després, a designar els senyors dels castells (2009, p. 50). Per la seva banda, Cropp destaca les fortes implicacions feudals de l'ús d'aquest terme en la lírica (1975, p. 26). 
dors: Dona presans, on grans valors s'alberga / mils podets far a vostres voluntats (Lluís Icart, Can me sove de la beutat diversa, vv. 9-10); dona valents o.s fis, pres d'agradatge, I prenon repaus ab vos cent vets lo dia (Bernat Serra, Pus so destret no.m tenguats a follia, vv. 39-40); De fi en fi, vos am tan finament / de fin'amors a vos, dona molt fina (Francesc Ferrer, De fi en fi vos am tan finament, vv. 1-2). Fins i tot la tendència vituperiosa inaugurada per Gui d'Ussel troba un camp fèrtil de cultiu a l'obra dels nostres poetes en la pràctica del maldit. Així, un artista com Joan Berenguer de Masdovelles, sempre disposat a explotar el vessant més violent de la lírica amorosa, no vacil·la a immortalitzar en la seva obra el personatge de la mala dona:

Be us degreu sser, mala dona, guardada

de scriur'aixi, ni metr'en mon poder

lletr'en lo mon, pus avieu voler

de no tenir la ffe per vos donada.

Joan Berenguer de Masdovelles, Ara conech sso que no conexia, vv. 49-52

Domna i midons són àmpliament utilitzats al llarg del segle XIV i també durant la primera meitat del $\mathrm{XV}$, quan comparteixen popularitat amb senyora. No obstant això, al llarg de la segona meitat del segle observem una davallada en l'ús de les dues primeres paraules en favor de la tercera ${ }^{15}$. Aquesta tendència s'explica pel fet que, com exposa Coromines, a partir de finals de l'Edat Mitjana el substantiu dona (i la variant domna, també present a la llengua catalana gràcies, precisament, a l'ús que n'havien fet els poetes) deixa d'estar restringit a l'ús original com a tractament de respecte i distinció equivalent a "senyora, dama". En efecte, aquest ús galant es va generalitzant $\mathrm{i}$ comença a desplaçar el substantiu fembra, que fins a aleshores s'havia emprat per designar els individus del gènere femení. D'aquesta manera, dona passa a emprar-se, en termes generals, com a mot contrastant d'home ${ }^{16}$. A la vista d'aquest procés, el terme senyora esdevé l'opció preferida per reflectir de manera fidel el tractament respectuós i honorífic que els poetes dispensen a les dames cantades.

15 La consulta dels dos termes al CICA confirma aquesta tendència.

16 Coromines 1980-2001, vol. III, pp. 174-176. 


\subsection{Poder}

\begin{tabular}{|c|c|c|}
\hline \multicolumn{3}{|r|}{ PODER } \\
\hline Èpoques & $\begin{array}{l}\text { Frequència } \\
\text { d'ús } \\
\text { (percentatge } \\
\text { de poemes en } \\
\text { què apareix) }\end{array}$ & Autors (nombre de poemes en què apareix/nombre total de poemes) \\
\hline Mitjan segle XIV & $100 \%$ & Anònim Florència, ms. Palat $1052(1 / 1)$ \\
\hline $\begin{array}{l}\text { Final del segle XIV- } \\
\text { inici del XV }\end{array}$ & $22 \%$ & Melcior de Gualbes (1/3), Gilabert de Próixita (4/20) \\
\hline $\begin{array}{l}\text { Primera meitat del } \\
\text { segle XV }\end{array}$ & $13 \%$ & $\begin{array}{l}\text { Joan Basset }(1 / 20) \text {, Andreu Febrer (1/15), Joseta (1/1), Amau March (1/6), Jordi de Sant Jordi (3/16), } \\
\text { Blai Seselles (1/2), Lluis de Vila-rasa (1/11) }\end{array}$ \\
\hline Mitjan segle XV & $6 \%$ & $\begin{array}{l}\text { Francesc Ferrer (1/10), Marti Garcia (1/11), Franci Guerau (1/7), Ausiàs March (4/128), Lluís de } \\
\text { Requesens (1/9), Pere Torroella (4/29) }\end{array}$ \\
\hline $\begin{array}{l}\text { Segona meitat del } \\
\text { segle XV }\end{array}$ & $10 \%$ & Joan Berenguer de Masdovelles (18/180) \\
\hline
\end{tabular}

A la documentació feudal, PODER, infinitiu substantivat format a partir de *POTERE, significa "domini o jurisdicció sobre un feu", tot i que és més freqüent trobar el terme POTESTAS amb aquest sentit ${ }^{17}$. L'ús del substantiu poder per part dels trobadors reflecteix l'accepció de "domini, senyoria" en el sentit feudal: Pois meus no sui et ilh m'a en poder (70, 42, v. 47; Bernart de Ventadorn, Can vei la flor, l'erba vert e la folha); Dona, si.us platz, aiatz humilitat / De mi que sui totz el vostre poder (30, 24, vv. 24-25; Arnaut de Maruelh, Tot quant eu faic ni dic que'm si'onrat); Car ieu mezeis m'anei metre cochos / en tal poder don era·m vau plaignen (167, 35, vv. 4-5; Gaucelm Faidit, Maintas sazos es hom plus voluntos).

Els poetes catalans i valencians, però, amplien significativament el ventall d'accepcions del terme en les seves composicions. Així, hi trobem versos en què poder és clarament sinònim de "domini, senyoria, jurisdicció", tot i que no són tan abundants com a la lírica dels seus antecessors:

Dona gentils e de tan excelhença té lo meu cor ten fort en son poder que-l sieu coman regira mon voler e fay de me segons sa conaxença.

Gilabert de Próixita, Amant languesch e languin pas gran pena, vv. 21-24

17 Rodón 1957, p. 198. 
En mal poders, enqueres en mal loch, hay mis mon cor e mon fat pensamen seguint amor e son foll mandamen, Jordi de Sant Jordi, En mal poders, enqueres en mal loch, vv. 1-3

Vos, qui $\cdot \mathrm{m}$ teniu tot en vostron poder, homilment prech que dir me tremetau que torn a vos, car pus avant no.m plau, ni en lo mon no tinch altre voler; Joan Berenguer de Masdovelles, Quan me ssove d'aquell jorn que parti, vv. 33-36

El sentit feudal del terme comparteix popularitat en aquest període amb altres accepcions de caràcter més ampli, com "força" o "esforç":

No·m maravelh si·s mostra de sa banda

Amors, danli de mon cor la fadigua, tolhenme sforç e poder que li diga so que de liey haver mon cor demanda.

Melcior de Gualbes, Pus me suy mes en l'amorosa questa, vv. 29-32

$$
\text { ez afeblir }
$$

de ley preyar e requerir

vey mon poder,

Andreu Febrer, Amors, qui tost fer, quan li play, vv. 24-26

Dona gentil e d'accellent natura que viu tots jorns en amoros voler deu per tostemps metre tot en son poder no mostrar may a altri s'amor pura, Blai Seselles, Dona gentil e d'accellent natura, vv. 1-4

L'ús més freqüent d'aquest terme, en qualsevol de les seves accepcions, es dóna al llarg de la primera meitat del segle XV. És significatiu el fet que els poetes aprofitin la diversitat de sentits del mot per emprar-lo en contextos que no permeten la interpretació tècnica feudal. Aquesta, com ja hem indicat més amunt, queda reduïda a uns quants testimonis ocasionals, que esdevenen pràcticament inexistents a mesura que avança el segle. 


\subsection{Franc, franca}

\begin{tabular}{|c|c|c|}
\hline \multicolumn{3}{|r|}{ FRANC, FRANCA } \\
\hline Èpoques & $\begin{array}{l}\text { Frequència } \\
\text { d'ús } \\
\text { (percentatge } \\
\text { de poemes en } \\
\text { què apareix) }\end{array}$ & Autors (nombre de poemes en què apareix/nombre total de poemes) \\
\hline $\begin{array}{l}\text { Primera meitat del } \\
\text { segle XIV }\end{array}$ & $27 \%$ & Joan de Castellnou (3/11) \\
\hline $\begin{array}{l}\text { Segona meitat del } \\
\text { segle XIV }\end{array}$ & $5 \%$ & Cançoneret de Ripoll (1/20) \\
\hline $\begin{array}{l}\text { Final del segle XIV- } \\
\text { inici del XV }\end{array}$ & $30 \%$ & Gilabert de Próixita $(6 / 20)$ \\
\hline $\begin{array}{l}\text { Primera meitat del } \\
\text { segle XV }\end{array}$ & $18 \%$ & $\begin{array}{l}\text { Andreu Febrer (2/15), Gabriel Ferrús (1/6), Lluís Icart (2/14), Guerau de Massanet (1/1), Aznar Pardo } \\
(1 / 2)\end{array}$ \\
\hline Mitjan segle XV & $5 \%$ & Marti Garcia (1/11), Pere Torroella (1/29) \\
\hline $\begin{array}{l}\text { Segona meitat del } \\
\text { segle XV }\end{array}$ & $2 \%$ & Romeu Llull (1/17), Joan Berenguer de Masdovelles (2/180), Antoni Vallmanya $(2 / 21)$ \\
\hline
\end{tabular}

Rodón Binué recull l'ús feudal de l'adjectiu FRANCUM, que defineix com "libre", y, aplicado a una tierra o posesión, "libre de cargas". Un dels exemples que esmenta és l'ús dels adjectius francas et legitimas aplicats a unes terres (Liber Feudorum Maior 314, abans de 1066) ${ }^{18}$. La coincidència d'aquests termes permet interpretar FRANCUM en un sentit més ampli que el que esmenta Rodón; un sentit que s'aproxima a "legítim", "autèntic". L'ús que fan els trobadors de l'adjectiu franch atesta l'existència d'aquesta connotació en occità, ja que sovint apareix acompanyat d'altres epítets positius ( $f i s, f i$ zels, leyal) que s'apliquen a l'amant: E cum li suy francx e leyals e fis $(17,1$, v. 22; Alegret, Aissi cum selh qu'es vencutz e sobratz); Per qu'eu li sui hom francs, fizels e fis $(364,33$, v. 19; Peire Vidal, Per mielhs sofrir lo maltrait e l'afan); Bona dona, fis e francx et adretz / vos ai estat e portat vostre lau (392, 25, vv. 25-26; Raimbaut de Vaqueiras, No puesc saber per que $\cdot m$ sia destregz).

Aquest ús perviu al llarg dels segles XIV i XV, i en certes ocasions apareix com a sinònim de sincer:

18 Rodón 1957, p. 125. 
Fort me desplay cant no vey

lieys de qui suy franch serven;

$$
(\ldots)
$$

De çay on suy la suppley

que no*s mostre malvolen

vas me, qui·l suy leyalmen

hom fis e franch per soffrire;

Gilabert de Próixita, Fort me desplay cant no vey, vv. 1-2 i 17-20

De ferm en ferm suy liguat ab la ferma

fferma d'amor, qui·m fa ser dobla ferm,

leyal he franch, (...)

Martí Garcia, De ferm en ferm suy liguat ab la ferma, vv. 1-3

anyell en praticar les gents

e fér lahó en ardiments,

franc e senser,

Pere Torroella, Tant mon voler s'és dat a·mors, vv. 513-515

L'ús laudatori de franc s'estén a la dama, de manera que trobem l'adjectiu aplicat a la seva persona o a alguna de les seves qualitats:

Ay! franca res, vostre pretz cabalos,

vostra beutat ses nuyla maestria

mesclad'am sen, ab joy e am cuyndia,

Joan de Castellnou, Dieus! E com soy alegres e joyos, vv. 25-27

Ay! cors avar, scas, richs de merce,

larges e franchs, de tot'onor complida,

lo mils del mon; si no us hay fayt per que,

las! com voletz axi fenir me vida?

Andreu Febrer, Ay! cors avar, scas, richs de merce, vv. 1-4

Sens e beutats ez onesta manera,

franchs aculhirs, joven e gentilesa,

valors e pretz, gays comports e franquesa,

ffay de vos cim, govern, mur e barrera;

Aznar Pardo, Leyaltat vol e bon dreg me comanda, vv. 33-36

Els exemples de l'ús de franc en el sentit tècnic feudal de "lliure" són escassos, però encara apareixen durant la segona meitat del segle XV:

Ffoll es aquell que·s veu franch e libert, que met son cor en servitut ten cruha, Romeu Llull, Gloriós es l'hom qui no sent d'amor, vv. 33-35

car vey me pres, caytiu, ssotsmes, de franch que ffuy, al temps que llibertat hagui, Joan Berenguer de Masdovelles, Amor: del mal que $\cdot m$ feu ten fort me duyll, vv. 5-6 
El vigor del terme al llarg dels segles XIV i XV és indiscutible, però sembla clar que l'èxit es veu afavorit per la flexibilitat en la interpretació i per la multiplicitat de sentits que ofereix. Aquesta diversitat permet als poetes explotar l'adjectiu en contextos que s'allunyen del sentit feudal.

\subsection{Humil}

\begin{tabular}{|l|l|l|}
\hline \multicolumn{3}{|c|}{ HUMIL } \\
\hline Ėpoques & $\begin{array}{l}\text { Frequència } \\
\text { d'ús } \\
\text { (percentatge } \\
\text { de poemes en } \\
\text { què apareix) }\end{array}$ & Autors (nombre de poemes en què apareix/nombre total de poemes) \\
\hline $\begin{array}{l}\text { Primera meitat del } \\
\text { segle XIV }\end{array}$ & $31 \%$ & Joan de Castellnou (3/11), Tomàs Peris de Foces (1/2) \\
\hline Mitjan segle XIV & $100 \%$ & Joan Blanch (1/1) \\
\hline $\begin{array}{l}\text { Segona meitat del } \\
\text { segle XIV }\end{array}$ & $10 \%$ & Cançoneret de Ripoll (2/20) \\
\hline $\begin{array}{l}\text { Final del segle XIV- } \\
\text { inici del XV }\end{array}$ & $26 \%$ & Melcior de Gualbes (1/3), Gilabert de Próixita (5/20) \\
\hline $\begin{array}{l}\text { Primera meitat del } \\
\text { segle XV }\end{array}$ & $11 \%$ & Joan Basset (1/20), Andreu Febrer (2/15), Lluís Icart (3/14), Guillem de Masdovelles (1/15) \\
\hline Mitjan segle XV & $20 \%$ & Francesc Sunyer (1/5) \\
\hline $\begin{array}{l}\text { Segona meitat del } \\
\text { segle XV }\end{array}$ & $5 \%$ & Joan Berenguer de Masdovelles (8/180), Joan Rois de Corella (1/17) \\
\hline
\end{tabular}

La concurrència dels termes HUMILIS, HUMILITAS, HUMILITER a la documentació feudal catalana medieval queda demostrada per l'ús constant que se'n fa, almenys entre 844 i 1196, sobretot en contextos relacionats amb sol-licituds i peticions ${ }^{19}$. Aquestes situacions proporcionaven als trobadors un bon pretext per establir analogies significatives amb les súpliques de l'amant cortès. En efecte, Dorothy R. Sutherland destaca l'ús que fan els poetes occitans dels termes humil, humilitatz, humilmen com a exemple de la transposició a la lírica del lèxic habitual en la documentació feudal per expressar idees paral·leles dins de la convenció cortesa. Cal precisar, però, que els trobadors aplicaven l'adjectiu humils tant a la dama com a l'amant, i les connota-

19 CODOLCAT. 
cions del terme eren diferents en cada $\operatorname{cas}^{20}$. Quan es tracta de la dama, no s'ha d'interpretar que la seva actitud sigui modesta, submisa ni obedient, sinó més aviat condescendent, gentil, refinada. Humils i humilitatz apareixen, doncs, com a contraris d'orgoillosa i orgoilh. Sutherland cita exemples d'aquesta interpretació, i afirma que l'especialització en aquest sentit ja s'havia donat en la documentació feudal abans que els trobadors comencessin a fer servir els termes en qüestió ${ }^{21}$ : Francs cors umils, gais e cortes! (70, 31, v. 54; Bernart de Ventadorn, Non es meravelha s'eu chan); e mostra·m q'umilitaz / l'a tant en poder / que bes m'en pot eschazer (155, 22, vv. 18-20; Folquet de Marselha, Us volers outracujatz); Qu'Humilitatz, Merces e Chausimens / m'en pot valer sol qu'a midons s'emprenda (370, 9, vv. 35-36; Perdigon, Lo mals d'amor ai eu ben totz apres).

Quan l'adjectiu humils apareix referit a l'amant, descriu la seva actitud submisa i servicial cap a la dama: Per so lor serai fis e car / humils e simples e leyaus (389, 18, vv. 38-39; Raimbaut d'Aurenga, Assatz sai d'amor ben parlar); Li sui ses totz contens / e fis amans / francs, umils e merceian (242, 76, vv. 79-81; Giraut de Bornelh, Sol c'Amor me plevis); A guiza de fin amador / ab franc cor, humil e verai (30, 2, vv. 1-2; Arnaut de Maruelh, A guiza de fin amador).

Aquesta duplicitat en l'ús continua produint-se al llarg dels segles XIV i XV. Així, l'adjectiu humil s'atribueix a la dama o a alguna de les seves característiques:

Ay bel cors clar, netz, ab gay pretz, pus vesets que-us am, con merce non havets? Gentil, bel abril, mays humil e plasen que re,

Cançoneret de Ripoll, No·m pux d'aymar vos estrayre; VI, vv. 4-7

totz le mons veu qu'es flor d'onor mundana, plena d'umil e benigna manera, Melcior de Gualbes, Pus me suy mes en l'amorosa questa, vv. 37-38

Qual us porà semblar en la bondat, ne.n lo perlar, abte, ge[n]til e fi, ab gest humil, donós e graciat?

Francesc Sunyer, Reyna de mi, prech Déu que us do bon jorn, vv. 5-7

20 Lavis 1972, p. 125; Cropp 1975, p. 172.

21 Sutherland 1956, pp. 201-202. 
Destaquem, a propòsit dels versos de Melcior de Gualbes, l'ús de l'adjectiu umil en un context que, lluny de fer recordar les ressonàncies feudals del terme, s'acosta més a la imatge beatífica de la dama que ofereixen els poetes italians del Dolce Stil Novo. Per la seva banda, Jaume Torró adverteix que, si bé l'ús d'humil per part de Francesc Sunyer pot fer pensar en Dante, el substantiu gest és habitual a la lírica catalana i castellana del segle $\mathrm{XV}^{22}$.

La humilitat també és una de les virtuts de l'amant, en el mateix sentit en què ho era a la lírica dels trobadors:

humils e clis vos ren la nuyt e $\cdot 1$ dia grat e merce, co's tayn, da genyolos, Joan de Castellnou, Dieus! E com soy alegres e joyos, vv. 11-12

A vos suplich, humils, ab testa clina, merce querin me vulhats enrequir de vostra amor, joyosa flor de lir,

Lluís Icart, Belha ses par, en pretz e laus s'abonda, vv. 5-7

Cruel virtut, que no la pogué vençre gest tan humil d'aquest, qui fón un fènix en vera amor, més amant que tot altre!

Joan Roís de Corella, En lletres d'or, tendreu en lo sepulcre, vv. $8-10$

L'ús de l'adjectiu humil a la lírica decau lleument durant la segona meitat del segle XV, especialment en els casos en què s'aplicava a la dama. Aquest ús, que Coromines identifica amb el sentit de quieto, pacifico, dolce que adopta el mot a Petrarca i a Dante, és, en efecte, més freqüent a la llengua catalana i occitana antiga ${ }^{23}$. Així, aquesta accepció de regust feudal va cedir el lloc a la interpretació de caràcter més ampli, que coincideix amb els usos aplicats a la figura de l'amant.

22 Torró 2009, p. 278.

23 Coromines 1980-2001, vol. IV, pp. 825-826. 


\subsection{Honor}

\begin{tabular}{|l|l|l|}
\hline \multicolumn{3}{|c|}{ HONOR } \\
\hline Èpoques & $\begin{array}{l}\text { Frequència } \\
\text { d'ús } \\
\text { (percentatge } \\
\text { de poemes en } \\
\text { què apareix) }\end{array}$ & Autors (nombre de poemes en què apareix/nombre total de poemes) \\
\hline $\begin{array}{l}\text { Primera meitat del } \\
\text { segle XIV }\end{array}$ & $9 \%$ & Joan de Castellnou (1/11) \\
\hline $\begin{array}{l}\text { Final del segle XIV- } \\
\text { inici del XV }\end{array}$ & $17 \%$ & Melcior de Gualbes (1/3), Gilabert de Próixita (3/20) \\
\hline $\begin{array}{l}\text { Primera meitat del } \\
\text { segle XV }\end{array}$ & $13 \%$ & Andreu Febrer (2/15), Lluís Icart (1/14), Jordi de Sant Jordi (3/16) \\
\hline Mitjan segle XV & $10 \%$ & Francesc Ferrer (1/10) \\
\hline $\begin{array}{l}\text { Segona meitat del } \\
\text { segle XV }\end{array}$ & $5 \%$ & Joan Berenguer de Masdovelles (7/180), Romeu Llull (2/17), Antoni Vallmanya (1/21) \\
\hline
\end{tabular}

El significat propi del substantiu HONOR, "dignitat", a la documentació de l'època feudal va evolucionar fins designar les terres atorgades en règim de feu que solien acompanyar la concessió de certes prerrogatives. Rodón Binué justifica aquest procés al·ludint a l'associació de conceptes entre la dignitat en sentit abstracte (per exemple, els càrrecs que concedia el rei) $\mathrm{i}$ els beneficis materials que aportaven aquestes concessions. D'aquesta manera, HONOR va arribar a emprar-se pràcticament com a sinònim de FEVUM ${ }^{24}$. Els trobadors de l'època clàssica van adoptar aquesta duplicitat de significats. Onor designava, per una banda, l'excel-lència espiritual que assoleix l'amant que practica l'amor noble, una interpretació que està en consonància, doncs, amb el privilegi que obté el dignitari d'un càrrec: E pois tan d'onor m'adutz I ben o dei a deu grazir, / que'l meils del mon sai cauzir (404, 4, vv. 1214; Raimon Jordan, Lo clar temps vei brunezir); Ab vos ai m'onor creguda (3, 3, v. 39; Aymar lo Negre, De solaz e de chanzos); Quar per s'amor esper en pretz montar / et en honor et en gran manentia $(248,88$, vv. 9-10; Guiraut Riquier, Yeu cujava soven d'amor chantar). Però també podia fer referència a la recompensa, habitualment de caràcter sensual, que l'amant esperava de la dama, i aquesta dimensió material de la gratificació s'aproximaria a la del FEVUM que rep aquell que és investit d'un honor ${ }^{25}$ : La plus bela d'amor /

24 Rodón 1957, pp. 141-142.

25 Cropp 1975, pp. 364-365. 
don aten tan d'onor (70, 44, vv. 19-20; Bernart de Ventadorn, Tant ai mo cor ple de joya); Quar m'a fait tanta d'onor, / que·m rete per servidor (364, 25, vv. 14-15; Peire Vidal, La lauzet'e $\cdot$ l rossinhol); E am dona aital cum la volria I tener elh bratz, quar mi seri'honors (223, 7, vv. 3-4; Guilhem Magret, Trop mielhs m'es pres qu'a'n Golfier de las Tors).

La pluralitat d'interpretacions del terme es manté, tot i que amb variacions, a la lírica dels poetes catalans i valencians ${ }^{26}$. Es conserva el sentit que acabem d'esmentar pel que fa a la dignitat que conquereix l'amant noble:

guazaynat ay plazer ses languimen;

honor ses mal, bela, faitz conquistar.

Joan de Castellnou, Valor ses frau, dona, tenetz en car, vv. 15-16

Car yeu m'encench d'amoros pensamen

cant pens de vos, qu'etz del mon plus valen

d'on m'es honor amar tal creatura.

Gilabert de Próixita, Pus que vos play, domna, que res no us dia, vv. 23-25

Per que'ls servins ab volentat Amor, atendre ferm poden guardo degut, e llur servey sera be conagut, e munteran en lo grau gran d'onor; Joan Berenguer de Masdovelles, Tots aquells mals c'Amor pot ffer sentir, vv. 33-36

En canvi, els versos en què honor designa la gratificació que atorga la dama són escassos, i no sempre fan referència directa a la recompensa que requereix l'amant, tal i com la trobàvem a les cançons dels trobadors:

per que sopley a vostra senyoria honor ten gran me fessats en cest lans, que, pus no us vey, de me siats membrans.

Lluís Icart, Si us am de cor e si desir que fos, vv. 48-50

Honor esper de vos, qui sou grayhida

de grans he pochs, e us veig tots jorns llouar

d'onestat gran; (...)

Joan Berenguer de Masdovelles, Vos no sentiu sso que sentir deuria, vv. 25-27

\footnotetext{
26 Coromines constata la convivència al llarg de l'Edat Mitjana d'honor en el sentit de "compensació material", de caràcter més popular, amb l'accepció culta de "dignitat" (19802001, vol. IV, p. 806). 
Aquesta accepció específica de l'entorn feudal va perdent presència per deixar pas a altres usos, com ara el de honor com a virtut de la dama:

e com havetz sus totes milhoria

d'onor, de sen e de belhesa gran,

Melcior de Gualbes, Acompanyat d'un amoros desir, vv. 5-6

que passa totes quantes son

de beutat, d'onor e de sen;

Andreu Febrer, Las, a qui dire ma langor?, vv. 123-124

A Deu coman a vos, que 1 mon honrats, c'al mig del cor portats Honor escrita.

Jordi de Sant Jordi, Sovint sospir, dona, per vos, de luny, vv. 35-36

Honor també apareix com a sinònim de "fama", "reputació":

Aquell amant que's veu d'amor sagat, sens mes pensar, li offereix la vida, dans e perills e la honor oblida,

Romeu Llull, Ffantesiant molt sovint en amor, vv. 41-43

car lo qui us diu es vostro ben volent

e va detras ffer vostr'onor decaure,

es anamich, e no.l deveu complaure (...)

Bens aveu molts, mas hu singularment

per lo qual sou justament stimada;

si no'l guardau, vostr'onor aterrada

sera, de çert, per tal deffalliment.

Joan Berenguer de Masdovelles, So que fins vuy aveu sabut guor-

dar, vv. 5-7 i 9-12

A la vista d'aquests exemples, queda clar que el terme honor gaudeix d'una certa salut al llarg dels segles XIV i XV, si bé els contextos on apareix es distancien de la connotació feudal que exhibia a les cançons dels trobadors de l'època clàssica. 


\subsection{Vassall}

\begin{tabular}{|l|l|l|}
\hline \multicolumn{3}{|c|}{ VASSALL } \\
\hline Èpoques & $\begin{array}{l}\text { Frequència } \\
\text { d'ús } \\
\text { (percentatge } \\
\text { de poemes en } \\
\text { què apareix) }\end{array}$ & Autors (nombre de poemes en què apareix/nombre total de poemes) \\
\hline $\begin{array}{l}\text { Primera meitat del } \\
\text { segle XIV }\end{array}$ & $50 \%$ & Tomàs Peris de Foces $(1 / 2)$ \\
\hline $\begin{array}{l}\text { Final del segle XIV- } \\
\text { inici del XV }\end{array}$ & $10 \%$ & Pau de Bellviure (1/1), Gilabert de Próxita (1/20) \\
\hline $\begin{array}{l}\text { Primera meitat del } \\
\text { segle XV }\end{array}$ & $10 \%$ & Joan Basset $(1 / 20)$, Lluís Icart (2/14), Arnau March $(1 / 6)$ \\
\hline Mitjan segle XV & $100 \%$ & Bernat Serra (1/1) \\
\hline $\begin{array}{l}\text { Segona meitat del } \\
\text { segle XV }\end{array}$ & $1 \%$ & Joan Berenguer de Masdovelles (2/180) \\
\hline
\end{tabular}

L'ús a la documentació llatina de VASSALUM, "aquell que ha retut homenatge a un senyor feudal" 27 , es reflecteix en l'ús que fan els trobadors dels termes vassal, vassalatge: E s'eu am so que no·m deu eschazer, / forsa d'amor m'i fai far vassalatge (70, 42, vv. 13-14; Bernart de Ventadorn, Can vei la flor, l'erba vert e la folha); E si.m solh eu tener so clam / com vassal de lor bos senhors / e no m'en sui del tot laissatz (242, 25, vv. 25-27; Giraut de Bornelh, Be conve, pos ja baissa'l ram); Qe cel es fols que fai fol vassalatge / e fols qui cre aver a son coman / tot so que ve plazen ni benestan $(167,59$, vv. 25-27; Gaucelm Faidit, Tant ai sofert longamen gran afan). Tanmateix, cal dir que l'ús d'aquest termes a la lírica occitana és esporàdic, i que és força més freqüent trobar l'adjectiu substantivat liges o el sintagma hom liges per identificar la relació que uneix l'amant amb la dama ${ }^{28}$ : Qu'ieu sui sos om liges, on que m'esteya (70, 42, v. 38; Bernart de Ventadorn, Can vei la flor, l'erba vert e la folha); E serai ricx, si $m$ vol en son servizi metre / silh cui hom liges sui ses dar e ses prometre (234, 16, vv. 5-6; Guillem de Saint Leidier, Pus tan mi fors'amors que mi fai entremetre); Liges soi sieus, mieltz que demieis (29, 1, v. 29; Arnaut Daniel, Amors e iois e liocs e tems). El Trésor de la Langue Française informatisé (TLFi) proposa, per al francès lige, l'origen d'un baix

27 Rodón 1957, p. 254.

28 El fet de ser hom liges d'un senyor implicava l'obligació de servir-lo per sobre de tots els altres senyors feudals que pogués tenir el vassall en qüestió. Tot i així, els Usatges de Barcelona codifiquen casos en què és possible tenir més d'un senyor ligi (Kagay 1994, p. 40). 
llatí *LAETICUS, LİTICUS, derivat de LETUS, LITUS, tots dos atestats a la Llei Sàlica. Remet a Niermeyer, que, efectivament, identifica l'origen de liges amb un LITICUS que procedeix, al seu torn, de LITUS, individu appartenant à une classe intermédiaire entre celle des hommes libres et celle des serf $s^{29}$. Aquest sentit coincideix amb el tipus de relació que uneix l'amant amb la dama a la lírica dels trobadors.

La presència d'aquests termes a la documentació feudal catalana és escassa. Eulalia Rodón Binué no en recull cap, i, segons CODOLCAT, al Liber Feudorum Maior hi apareixen, en una ocasió, LIGIAM (1153) i, en una altra, LIGERE (entre 1028 i 1047). Aquesta tendència està en consonància amb el fet que els poetes catalans i valencians no utilitzin el terme. Per contra, sí que empren vassall, vassallatge i vassallia:

Mala fiu anch conort de mon dampnatge, pensan que'b vos posques tant conquerir, que si us amas volen vos cartenir, que vos plagues, dona, mon vessalhatge.

Gilabert de Próixita, Pus qu'en turmen hay mis tostemps ma vida, vv. 25-28

car yeu de vos suy, en fizel amans, vassalhs caytius, belha senyora mia,

Lluís Icart, Si us am de cors e si desir que fos, vv. 41-42

e de fin cor vos liure vassallia,

pus Deu vos fech d'alta sanch e paratge;

Bernat Serra, Pus so destret no.m tenguats a follia, vv. 4-5

Crida l'atenció el fet que, aproximadament, un 20\% dels escassos testimonis de l'ús d'aquests termes aparegui en el context d'un maldit:

Donchs, ¿per que u fayts? ¿Cuydats fer benifici

en dar la mort hun sol vassall aflicte?

Pau de Bellviure, Domna gentil, vos m'enculpats a tort, vv. 29-30

Pus me' tingues jus vostre vesselhatge,

n'avets jugat tots jorns a la pilota,

es a la fi m'avets dada tal sota

disen que·m luny de vos en mal viatge.

Joan Basset, Yeu vos requir, Na ladria malvada, vv. 33-36

En el primer dels dos articles que Pierre Bec dedica a l'anàlisi de l'univers poètic del dolor a l'obra de Bernart de Ventadorn, l'estudiós explica

29 Niermeyer 1976, pp. 615-616. 
com la dimensió jurídica del substantiu dan justifica la gosadia de l'amant, que s'atreveix a criticar l'amor i la dama pels mals que li han causat ${ }^{30}$. De manera paral·lela a l'argumentació de Bec, l'ús dels termes vassall i vesselhatge en els versos citats implica una sèrie d'obligacions jurídiques que la dama ha de respectar. El comportament de la senyora respecte del seu vassall no correspon al que dicta la justícia; en conseqüència, ella perd els seus drets i l'amant se sent autoritzat per criticar-la amb el suport de la legalitat ${ }^{31}$.

Com que l'ús d'aquests termes a la lírica dels trobadors no es pot qualificar d'abundant, la davallada en la frequiència d'ús que trobem a la lírica catalana i valenciana sembla l'evolució natural de la tendència a abandonar progressivament els mots més reminiscents del món feudal i menys susceptibles de ser adaptats a altres contextos.

\subsection{Obediència}

\begin{tabular}{|l|l|l|}
\hline \multicolumn{2}{|c|}{ OBEDIÈNCIA } \\
\hline Ėpoques & $\begin{array}{l}\text { Frequència } \\
\text { d'ús } \\
\text { (percentatge } \\
\text { de poemes en } \\
\text { què apareix) }\end{array}$ & Autors (nombre de poemes en què apareix/nombre total de poemes) \\
\hline $\begin{array}{l}\text { Final del segle XIV- } \\
\text { inici del XV }\end{array}$ & $5 \%$ & Gilabert de Próixita (1/20) \\
\hline $\begin{array}{l}\text { Primera meitat del } \\
\text { segle XV }\end{array}$ & $7 \%$ & Andreu Febrer (1/15), Lluís Icart (1/14) \\
\hline $\begin{array}{l}\text { Mitjan segle XV } \\
\text { Segona meitat del }\end{array}$ & $1 \%$ & Ausiàs March (1/128) \\
\hline segle XV & $2 \%$ & Joan Berenguer de Masdovelles (3/180) \\
\hline
\end{tabular}

Dorothy R. Sutherland destaca la presència dels termes obediens i obediensa al llarg de tota la tradició trobadoresca occitana, i afirma que, malgrat l'ús eminentment eclesiàstic d'aquests mots als testimonis escrits medievals, també es podien trobar en documentació feudal, on OBEDIENTIA actuava com a terme equivalent a HOMAGIUM ${ }^{32}$. Efectivament, l'ús d'aquestes paraules en la documentació eclesiàstica supera amb escreix l'ús feudal, però tant $\mathrm{Du}$

30 Bec 1968, p. 565.

31 Per a les conseqüències de la ruptura dels compromisos feudals per part del senyor, vegeu Bloch 1940, p. 258.

32 Sutherland 1956, pp. 199-200; també ho constata Cropp 1975, p. 117. 
Cange com CODOLCAT ofereixen examples d'aquest darrer. És a través de la documentació feudal, segons Sutherland, que aquests termes van arribar a la lírica dels trobadors: Pos sers obediens / li sui sens totz contens $(242,76$, vv. 78-79; Giraut de Bornelh, Sol c'Amors me plevis); C'ades serai / en sa franca manaia / obediens / a son gen cors cortes (167, 11, vv. 21-24; Gaucelm Faidit, Ben for'oimai); Sui vostres bendizens / e sers obediens (364, 24, vv. 22-23; Peire Vidal, Ges pel temps fer e brau).

Aquest ús inspirat en les relacions feudals disminueix al llarg dels segles XIV i XV. Són pocs els versos en què l'amant declara la seva obediència cap a la dama:

Vostre suy yeu, dompna, non pas de me, per qu'yeu vos dey temer ez obesir;

Andreu Febrer, E lhas, amors! Ten pauch vos cal de me, vv. 33-34

ans, com bon cerffs, ab grand'obediença, serviray ley he qui servir me ffa,

Joan Berenguer de Masdovelles, Eres pus vey c'Amors vol que sieus sia, vv. 5-6

És curiós que, en un cas, l'amant admeti que les sospites negatives de la dama estan basades en el fet que ell no li dedica obediència:

e vos pensau, gentil, que us vulla mal, pus que no us veig ne us fas hobediença?

Joan Berenguer de Masdovelles, Pus vos, mon be, ab vostra gran bellesa, vv. 19-20

Potser Joan Berenguer de Masdovelles reflecteix la nova sensibilitat del seu públic, per a la qual les fórmules feudalitzants de la poesia amorosa ja no són estèticament rellevants. L'anàlisi del proper terme ens proporcionarà més dades per confirmar o rebutjar el vigor d'aquesta tendència.

\subsection{Homenatge}

\begin{tabular}{|l|l|l|}
\hline \multicolumn{3}{|c|}{ HOMENATGE } \\
\hline & $\begin{array}{l}\text { Frequència } \\
\text { d'ús } \\
\text { (percentatge } \\
\text { de poemes en } \\
\text { què apareix) }\end{array}$ & Autors (nombre de poemes en què apareix/nombre total de poemes) \\
\hline $\begin{array}{l}\text { Primera meitat del } \\
\text { segle XV }\end{array}$ & $7 \%$ & Andreu Febrer (1/15) \\
\hline Mitjan segle XV & $3 \%$ & Francí Guerau (1/7), Ausiàs March (1/128), Pere Pou $(1 / 1)$, Bernat Serra $(1 / 1)$ \\
\hline
\end{tabular}


El terme HOMINATICUM designava l'acte pel qual un individu es feia HOMO d'un senyor, i aviat aquest sentit es va estendre per incloure, a més de la cerimònia, el vincle de dependència que unia el vassall i el senyor. Rodón Binué destaca la freqüència d'ús del terme en època feudal i les connotacions que va adquirir de sumisión y respeto i muestra de afecto y consideración ${ }^{33}$. El concepte d'homenatge és, doncs, implícit en l'ètica amorosa dels trobadors, però alguns d'ells van decidir emprar el terme per expressar el concepte amb absoluta propietat ${ }^{34}$ : qu'eu no cre, s'ilh o jura, / refut mon omenatge (392, 27, vv. 23-24; Bernart de Ventadorn, Can lo dous temps comensa); Mais ar m'agr'obs bons vers o tals chansos / c'azautes lei cui fas lige homenatge (234, 11, vv. 3-4; Guilhem de Saint Leidier, Estat aurai estas doas sasos); Serai aclis vas lo sieu senhoratge / cum s'ieu l'agues fait certain homenatge (366, 13, vv. 11-12; Peirol, D'un bon vers vau pensan com lo fezes).

Els poetes catalans i valencians no fan un ús extensiu d'aquest terme, i en la majoria de casos en què apareix es parla de l'homenatge que es ret a l'amor:

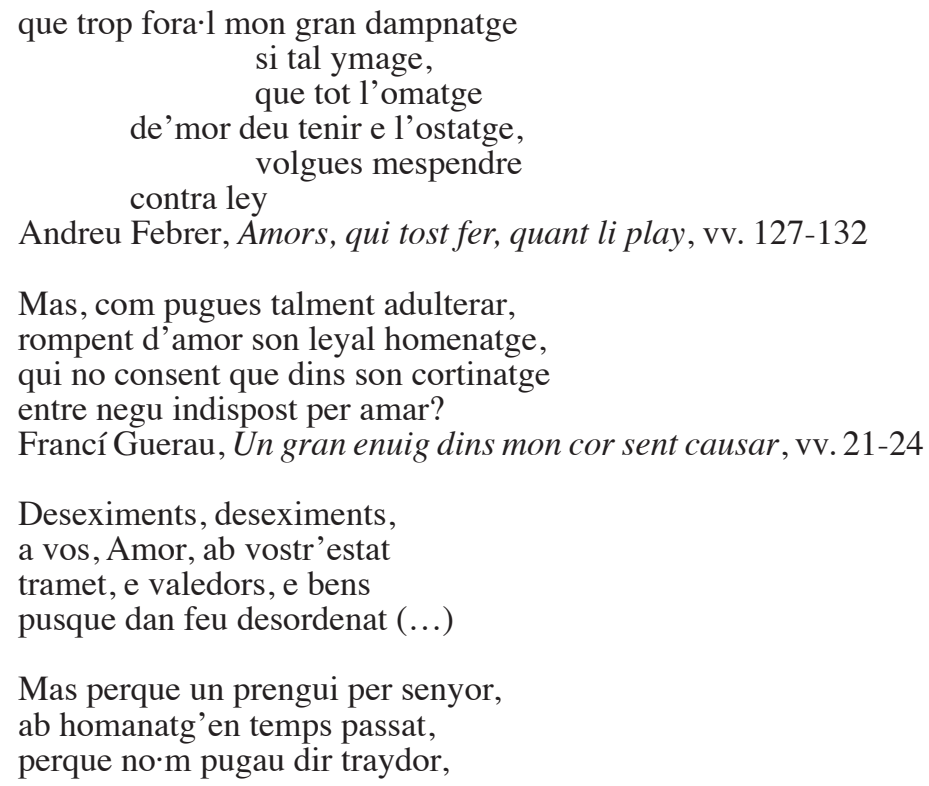

Mas, com pugues talment adulterar, rompent d'amor son leyal homenatge, qui no consent que dins son cortinatge entre negu indispost per amar?

Francí Guerau, Un gran enuig dins mon cor sent causar, vv. 21-24

Deseximents, deseximents, a vos, Amor, ab vostr'estat tramet, e valedors, e bens pusque dan feu desordenat (...)

Mas perque un prengui per senyor, ab homanatg'en temps passat, perque no·m pugau dir traydor,

33 Rodón 1957,pp. XV i 136-138. Bloch cita la presència del mot HOMAGIUM com a exemple d'una pràctica dels notaris a l'hora de transcriure en llatí transaccions orals en llengua romanç: en ocasions, es limitaven a afegir una terminació llatina a un mot que s'havia emprat en llengua vernacla $(1939$, p. 125). CODOLCAT recull quatre testimonis de l'ús del terme entre 1190 i 1236 (?).

34 Alfonsi 1986, p. 199. 
ab dasamor,

vull, molt cuytat,

esser me de vos desnaturat.

Pere Pou, Deseximents, deseximents, vv. 1-4 i 54-59

Les referències a l'homenatge que rep la dama són escadusseres:

per ço'us supley que'm prenats l'omenatge

per remeyar mon dols e ma feunia.

Bernat Serra, Pus so destret no'm tenguats a follia, vv. 7-8

Si bé s'adverteix una certa vigència del mot a mitjan segle XV, l'ús no resisteix el pas del temps i sembla decaure a partir d'aquest moment. Les fortes connotacions feudals del terme en limiten l'ús i el condicionen a un marc de referència prou restringit.

\subsection{Home}

\begin{tabular}{|c|c|c|}
\hline \multicolumn{3}{|r|}{ HOME } \\
\hline Èpoques & $\begin{array}{l}\text { Frequència } \\
\text { d'ús } \\
\text { (percentatge } \\
\text { de poemes en } \\
\text { què apareix) }\end{array}$ & Autors (nombre de poemes en què apareix/nombre total de poemes) \\
\hline $\begin{array}{l}\text { Final del segle XIV- } \\
\text { inici del XV }\end{array}$ & $10 \%$ & Gilabert de Próixita $(2 / 20)$ \\
\hline $\begin{array}{l}\text { Primera meitat del } \\
\text { segle XV }\end{array}$ & $6 \%$ & Andreu Febrer (1/15), Jordi de Sant Jordi (1/16) \\
\hline $\begin{array}{l}\text { Segona meitat del } \\
\text { segle XV }\end{array}$ & $0,5 \%$ & Joan Berenguer de Masdovelles (1/180) \\
\hline
\end{tabular}

L'ús d'HOMO com a sinònim de "vassall" és comú en època feudal ${ }^{35}$. Els trobadors illlustren a bastament aquesta accepció en les seves cançons: Vostr'om sui juratz e plevitz (70, 33, v. 31; Bernart de Ventadorn, Pel doutz chan quel rossinhols fai); Vostr'om sui e vostr'om mi ren (167, 17, v. 29; Gaucelm Faidit, Coras qe-m des benananssa); Sos amics e so servire / e sos hom sui e serai (457, 1, vv. 34-35; Uc de Sant Circ, Aissi cum es coinda e gaia). La davallada en la frequència d'ús en la lírica catalana i valenciana respecte a l'occitana és notable. Així, només trobem unes quantes mostres de la interpretació feudal del mot, ja sigui en referència a la senyoria de la dama o a la de l'amor:

\footnotetext{
35 Rodón 1957, pp. XXII i 138-141.
} 
Donchs, pus vesets qu'yeu no me·n pux pertire, tan suy aclis, dona, per vostr'amor, entretostemps fayts me tanta d'onor que.m vulhats sol per vostr'om retenire; Andreu Febrer, Are $\cdot m$ platz be com l'afan e $\cdot 1$ martire, vv. 49-52

Mas celhs qu'amor vol per son home pendre tot son plet met en veray pretz muntar,

Jordi de Sant Jordi, No pot ren dir ne far que be estia, vv. 17-18

m'a pres Amor, dir no sabria com, e ffer me vol son vassall he son hom, Joan Berenguer de Masdovelles, En temps d'enuig e mig desllibertat, vv. 6-7

L'escassetat dels testimonis dóna fe de la decadència de l'accepció feudal del mot entre el públic d'aquests poetes.

\subsection{Baylia}

\begin{tabular}{|l|l|l|}
\hline \multicolumn{3}{|c|}{ BAYLIA } \\
\hline Èpoques & $\begin{array}{l}\text { Frequència } \\
\text { d'ús } \\
\text { (percentatge } \\
\text { de poemes en } \\
\text { que apareix) }\end{array}$ & Autors (nombre de poemes en què apareiz/nombre total de poemes) \\
\hline $\begin{array}{l}\text { Primera meitat del } \\
\text { segle XV }\end{array}$ & $7 \%$ & Guillem de Masdovelles (1/15) \\
\hline $\begin{array}{l}\text { Segona meitat del } \\
\text { segle XV }\end{array}$ & $1,5 \%$ & Joan Berenguer de Masdovelles (3/180) \\
\hline
\end{tabular}

Eulalia Rodón Binué identifica tres accepcions diferents del terme llatí BAIULIA a la documentació feudal catalana: 1) administració d'un conjunt de béns en representació d'un senyor; 2) tutela i protecció de menors i administració dels béns d'aquests, i 3) protecció que els grans senyors exercien sobre persones o llocs determinats que es col-locaven sota la seva tutela; aquesta protecció era remunerada amb una compensació en espècies que acordaven les dues parts ${ }^{36}$. És aquesta tercera interpretació la que exemplifiquen les aparicions del mot a la lírica dels trobadors: Ses cor viu, car ab me no l'ai, I qu'ilh l'a en bailia! (242, 2, vv. 23-24; Giraut de Bornelh, Ab semblan me fai

\footnotetext{
36 Rodón 1957, pp. 33-36.
} 
dechazer); per que no.m plai remanha / jamais mos cors en sa falsa baylia, I ni ja Dieus mais no'm do sa senhoria (457, 7, vv. 20-22; Uc de Sant Circ, Be fai granda follor); No fuy en ma baylia / enans ai estat languen / fis en sa senhoria (225, 14 / 437, 30, vv. 64-66; Guilhem de Montanhagol i Sordel, Senh'en Sordelh, mandamen).

Com en els casos d'altres termes amb fortes connotacions feudals, l'ús de baylia cau en franca decadència durant els segles XIV i XV. A més, dels pocs exemples que en trobem, pràcticament la meitat fa referència a la baylia de l'amor, en comptes de fer al-lusió al domini de la dama:

Sapjats, senyors, quez ab son bell semblan

falç monsongier, que tots jorns me fazia,

m'a detengut llonch temps jus sa baylia,

estro que vench l'altre quez ayma tan,

Guillem de Masdovelles, Ja no veyra mi-doncs que pus la blan, vv. $17-20$

Abans, ab sa gran senyoria,

l'arbitre franch m'a tot llevat, hi aquell mes jus la ballia

de la qui no m'a piatat,

Joan Berenguer de Masdovelles, Amor tots jorns me presenta, vv. 5-8

mas ffin'Amor, qui te jus sa baylia

les gens del mon, que no'n pot escapar

ges hun tot ssol, ha volgut mi donar

menys de mon seny, qui.l contrari volia.

Joan Berenguer de Masdovelles, Yeu vull ez am la plus bella que's mir, vv. 29-32

\subsection{Bauzia}

\begin{tabular}{|l|l|l|}
\hline \multicolumn{3}{|c|}{ BAUZIA } \\
\hline Ėpoques & $\begin{array}{l}\text { Frequència } \\
\text { d'ús } \\
\text { (percentatge } \\
\text { de poemes en } \\
\text { què apareix) }\end{array}$ & Autors (nombre de poemes en què apareix/nombre total de poemes) \\
\hline $\begin{array}{l}\text { Segona meitat del } \\
\text { segle XIV }\end{array}$ & $10 \%$ & Cançoneret de Ripoll (2/20) \\
\hline
\end{tabular}

Un altre terme de fortes ressonàncies feudals és BAUSIA, que Rodón Binué defineix com delito de traición contra el señor feudal i incumplimiento de la fidelidad prometida en el acto del vasallaje ${ }^{37}$. Els trobadors l'incorporen

\footnotetext{
37 Rodón 1957, pp. 42-43.
} 
al seu repertori lèxic, habitualment dins del sintagma ses bauzia, per exalçar la lleialtat del servei de l'amant: si cum yeu l'am finamen ses bauzia $(17,1$, v. 21; Alegret, Aissi cum selh qu'es vencutz e sobratz); Et eu am la de fin cor, ses bauzia (364, 7, v. 5; Peire Vidal, Baros de mon dan covit); qu'ie us mi don ses bauzia (82, 3, v. 34; Bertran Carbonel, Aissi com sel qu'entrels pus assaians). La presència d'aquest mot a la lírica catalana i valenciana és escassísima, sobretot al llarg de la segona meitat del segle XIV i durant el XV, ja que, per ara, només l'hem pogut localitzar al Cançoneret de Ripoll:

car a vos port amor fina,

ni en als desirs ent[en]

mas vos servir ses bausia.

Cançoneret de Ripoll, Amorosa mayhorquina; I, vv. 15-17

Midons qu'eu aym ses bausia,

de cor vos prey humilment

que $m$ aydets per cortesia.

Cançoneret de Ripoll, Midons qu'eu am ses bausia; XVI, vv. 1-3

El mot bauzia encara s'emprava a la documentació jurídica catalana, si més no, durant els primers decennis del segle XIV ${ }^{38}$. No es pot descartar la possibilitat que un estudi més exhaustiu reveli la presència d'altres exemples a la lírica, però, en qualsevol cas, la tendència a deixar de banda aquest i altres termes amb connotacions feudals ben marcades queda fora de dubte.

\section{CONCLUSIONS}

A la vista d'aquest procés, una pregunta s'imposa: fins a quin punt el dret feudal era present a les vides dels poetes catalans i valencians dels segles XIV i XV i del seu públic? La vigència del dret feudal durant els darrers segles de l'Edat Mitjana es posa de manifest en diversos testimonis: veiem, per exemple, que, a la dècada de 1380 , Francesc Eiximenis destaca la necessitat de respectar les obligacions de fidelitat que el contracte feudal imposa sobre senyor i vassall ${ }^{39}$. La influència de l'imaginari del feudalisme es fa sentir, també, en esdeveniments de caràcter cultural i polític. Així, a l'inici del segle XV, algunes de les cerimònies que acompanyaven la concessió de la joia als poetes guanyadors dels certàmens literaris del Consistori de Barcelona mantenien

38 Lloret 2006, p. 179. Com indica Lloret, aquests casos de traïció no apareixen codificats als Usatges de Barcelona fins a mitjan segle XII (Kagay 1994, p. 42).

39 Eiximenis 1927, pp. 95-99; capítol XV ("Que los prínceps als pobles se deuen servar fealtat entre sí mateixos e en quines coses, e dels mals consellers dels prínceps"). 
analogies amb rituals feudals (per exemple, amb l'adobament d'un cavaller); el 1466, Renat d'Anjou accepta la submissió del principat de Catalunya en una cerimònia altament ritualitzada, plena de reminiscències feudals que posaven en relleu el compromís del senyor i l'obediència dels vassalls ${ }^{40}$.

Però la vigència del feudalisme no es limitava a un plantejament ètic ni a un conjunt de símbols presents a la cultura i a la política. Les estructures feudals compartien espais amb els règim de govern urbà $i$ amb el poder reial, en una pluralitat de marcs de referència legals a la qual tornarem més endavant ${ }^{41}$. Així, a les corts que se celebraven a la corona d'Aragó durant el segle $\mathrm{XV}$, juntament amb individus d'origen urbà procedents de famílies que havien accedit a la noblesa en les generacions més recents, s'hi trobaven els representants del braç militar, hereus dels llinatges nobles més antics, que, tot i ser un grup minoritari, defensaven una concepció purament feudal del poder, segons la qual el servei al monarca consistia en la prestació militar personal,i no pas en la concessió d'uns ajuts econòmics que la corona reclamava periòdicament ${ }^{42}$. Aquestes necessitats financeres de la corona, justament, proporcionaven a la burgesia un mitjà per accedir a la possessió de terres, que rebia a canvi dels seus favors econòmics al monarca. D'aquesta manera, en un procés que es va accentuant al llarg dels segles XIV i XV, la burgesia s'incorpora al sistema de propietat feudal, que deixa de ser patrimoni exclusiu de la noblesa i de l'església. De fet, les similituds entre l'oligarquia urbana i la baixa noblesa són cada cop més evidents, fins al punt que. l'any 1447, els consellers de Barcelona consideren els dos grups equiparables ${ }^{43}$.

Tanmateix, i com hem apuntat més amunt, el dret feudal vigent convivia amb altres sistemes jurídics, especialment amb el dret romà, que, a partir del segle XII, va prenent terreny a les lleis de caràcter personal i feudal, però sense arribar a desplaçar-les. El renaixement que experimenta el dret romà durant els darrers segles de l'Edat Mitjana es deu, en part, al fet que ofereix un sistema jurídic sistemàtic i detalladament articulat, una coherència que la corona, la noblesa i les agrupacions municipals reconeixen i pretenen utilitzar en la defensa dels seus interessos ${ }^{44}$. Precisament, un dels col-lectius socials emergents a la corona d'Aragó a partir de la segona meitat del segle XIV és el dels juristes i els notaris, instruïts, entre altres disciplines, en dret romà. L'autoritat que aquests individus exercien en el domini de la justícia els va permetre ac-

\footnotetext{
${ }^{40}$ Tavani 1980, p. 21; Péquignot 2013, p. 628.

${ }^{41}$ Vicens i Vives 1956, p. 14; Valdeón, Salrach, Zabalo 1980, p. 299; Péquignot 2013, p. 398.

${ }^{42}$ Lafuente, Abella 2013, p. 438.

${ }^{43}$ Sabaté 1998, pp. 132-139; 2009, p. 271.

${ }^{44}$ Kagay 1994,pp. 1-2; Sabaté 2013, pp. 58-59.
} 
cedir a l'administració reial i els va obrir les portes d'accés a la noblesa ${ }^{45}$. És probable (i, de fet, en alguns casos s'ha constatat que és un fet) que aquests professionals del dret, desitjosos de consolidar la noblesa recentment adquirida, participessin activament a la vida literària practicant la poesia d'arrels trobadoresques, tradicionalment associada amb la noblesa feuda ${ }^{46}$. L'exposició a un grup variat i divers de sistemes jurídics, amb el qual convivien tant els poetes com el seu públic, justifica l'abandonament progressiu de la metàfora feudal per descriure la relació entre l'amant i la dama a la lírica amorosa. D'aquesta manera, la davallada en la frequència d'ús dels termes amb més reminiscències feudals no és pas un indicador de la decadència d'aquest codi legal, sinó una conseqüència del nou lloc que aquest sistema jurisdiccional ocupava entre d'altres.

Pel que fa a la resta de característiques de la lírica amorosa catalana i valenciana dels segles XIV i XV, no es pot negar la dependència respecte de la tradició trobadoresca. Els poetes en mantenen les convencions pel que fa a l'ètica i a la retòrica amoroses. Aquest fet sembla natural si considerem que els trobadors de l'època clàssica encara eren el principal referent literari, si més no, al principat de Catalunya, com ho demostra el fet que, l'any 1413, Felip de Malla cités Arnaut Daniel (actiu durant el segle XII) com a representant de la cultura catalana, mentre que considerava Jean de Meun (mort el 1305) ambaixador de la francesa, i, com a representant de la italiana, esmentava Dante Alighieri (mort el 1321) ${ }^{47}$. Alguns autors han atribuït la fidelitat dels nostres poetes als models trobadorescos al desig de perpetuar les convencions pròpies de l'antiga noblesa feudal, en la pretensió de legitimar la posició de prestigi social que molts d'ells havien adquirit recentment. És una argumentació ben fonamentada; tanmateix, si aquest esperit arcaic s'hagués aplicat fins a les últimes conseqüències, no hauríem observat cap evolució a la baixa en l'ús del lèxic feudal. Per contra, el que hi trobem és l'abandonament d'algunes de les paraules pròpies del llenguatge tècnic del feudalisme que, en els documents jurídics, continuaven fent-se servir: aquest procés indica una voluntat dels poetes d'adaptar-se a les exigències d'un públic que no és el dels seus admirats trobadors. És cert que, entre el públic d'aquests poetes, hi devia haver mem-

45 Hillgarth 1978, p. 68; Lafuente, Abella 2013, p. 434.

46 Ourliac explica com, després d'una primera etapa, en què els trobadors es mostraven hostils cap al dret romà perquè l'identificaven amb la ideologia de la croada albigesa i dels inquisidors, els juristes van adquirir un paper fonamental en la defensa i el manteniment de la lírica de tradició trobadoresca $(1965$, p. 173). Per la seva banda, Bisson constata la influència dels gustos de la noblesa en l'estil de vida i en les activitats culturals de les elits urbanes al final de l'Edat Mitjana (dins de les quals hi havia advocats i notaris; 1986, p. 176). També ho fa, en termes més dramàtics, Tavani 1980, p. 16.

47 La cita es troba a Tavani 1980, p. 18. 
bres de l'antiga noblesa i també burgesos que havien ingressat recentment en el sistema de propietat feudal, però també s'hi devien trobar ciutadans que no posseïen terres o que s'havien instal·lat en un nucli urbà, precisament, per alliberar-se de les imposicions que exigia el vincle feudal. Si pensem en el teixit social divers de les ciutats de la corona d'Aragó a la baixa Edat Mitjana, és lògic suposar que alguns individus no estiguessin prou familiaritzats amb el lèxic i els conceptes feudals com per copsar-ne totes les ressonàncies poètiques. Aquest factor influeix, també, en la tendència a deixar de banda el lèxic especialitzat de les relacions vassallàtiques.

La poesia amorosa dels segles XIV i XV és el producte d'una època convulsa i diversa, i l'anàlisi de les seves característiques ens ajuda a aprofundir en el coneixement d'aquell moment històric. Per aquesta raó, necessitem abordar-ne l'estudi des d'un punt de vista honest i sense prejudicis, lluny de comparacions desavantatjoses amb les tradicions anteriors i contemporànies. En comptes de lamentar la suposada manca d'originalitat dels poetes, seria més fructífer preguntar als textos per què mantenen alguns ingredients de la tradició anterior mentre que d'altres s'abandonen, i quins criteris segueixen els artistes per adaptar-se als gustos del seu públic. La identitat de la poesia catalana del final de l'Edat Mitjana encara està per construir, i l'article que hem presentat és una contribució a aquesta tasca. Esperem que n'hi hagi moltes més.

\section{BIBLIOGRAFIA CITADA}

Alfonsi, Laura Resnick (1986), Masculine Submission in Troubadour Lyric, Nova York, Peter Lang.

Bec, Pierre (1968), La douleur et son univers poétique chez Bernard de Ventadour: essai d'analyse systématique, "Cahiers de Civilisation Médiévale" 11 , pp. 545-571.

Bisson, Thomas N. (1986), The Medieval Crown of Aragon: A Short History, Oxford, Clarendon Press.

Bisson, Thomas N. (2009), The Crisis of the Twelfth Century: Power, Lordship and the Origins of European Government, Princeton - Oxford, Princeton University Press.

Bloch, Marc (1939), La société féodale, 1: la formation des liens de dépendance, París, Albin Michel.

Bloch, Marc (1940), La société féodale, 2: les classes et le gouvernement des hommes, París, Albin Michel.

Cabré, Miriam; Martí, Sadurní; Navàs, Marina (2009), Geografia i història de la poesia occitanocatalana del segle XIV, dins Alberni, Anna; Badia, Lola; Cabré, Lluís (eds.), Translatar i transferir: la transmissió de 
textos $i$ el saber (1200-1500), Santa Coloma de Queralt, Obrador Edèndum - Publicacions URV, pp. 349-376.

Coromines, Joan (1980-2001), Diccionari etimològic i complementari de la llengua catalana, 10 vols., Barcelona, Curial.

Corpus Documentale Latinum Cataloniae (CODOLCAT) http://gmlc.imf. csic.es/codolcat [consulta: 29/07/2014].

Corpus Informatitzat del Català Antic (CICA) http://www.cica.cat/index.php [consulta: 09/08/2014].

Corral Díaz, Ester (1996), As mulleres nas cantigas medievais, A Coruña, Edicios do Castro.

Cropp, Glynnis M. (1975), Le vocabulaire courtois des troubadours de l'époque classique, Ginebra, Droz.

Du Cange, Charles (1883-1887), Glossarium mediae et infimae latinitatis, Niort, L. Favre.

Eiximenis, Francesc (1927), Regiment de la cosa pública, ed. Daniel de Molins de Rei, Barcelona, Barcino.

Girolamo, Costanzo di (2010), L’herència dels trobadors a Catalunya, dins Hauf, Albert (dir.), Panorama crític de la literatura catalana, I: Edat Mitjana. Dels orígens a principis del segle XV, Barcelona, Vicens Vives.

Hillgarth, Jocelyn Nigel (1978), The Spanish Kingdoms, 1250-1516. Volume 2: 1410-1516, Castilian Hegemony, Oxford, Clarendon Press.

Kagay, Donald J. (1994), The Usatges of Barcelona: The Fundamental Law of Catalonia, Filadèlfia, University of Pennsylvania Press.

Lafuente Gómez, Mario; Abella Samitier, Juan (2013), La baja nobleza aragonesa después del Compromiso de Caspe: movilidad social y estrategias políticas (1412-1436), dins Falcón, Isabel (coord.), El compromiso de Caspe (1412), cambios dinásticos y constitucionalismo en la Corona de Aragón, Zaragoza, Obra Social de Ibercaja, pp. 432-442.

Lavis, Georges (1972), L'expression de l'affectivité dans la poésie lyrique française du Moyen Âge, XIIe-XIIIe siècles : étude sémantique et stylistique du réseau lexical joie-dolor, París, Belles Lettres.

Lloret, Albert (2006), Modelos jurídicos y reformas sociales en el Llibre de l'orde de cavalleria de Ramón Llull, "La Corónica: A Journal of Medieval Hispanic Languages, Literatures, and Cultures" 35/1, pp. 171-190.

Niermeyer, Jan Frederik (1976), Mediae latinitatis lexicon minus, Leiden, Brill.

Ourliac, Paul (1965), Troubadours et juristes, "Cahiers de civilisation médiévale" 30, pp. 159-177.

Péquignot, Stéphane (2013), Négocier la sujétion? Les catalans et le choix de nouveaux seigneurs durant la "guerre civile catalane”, dins Falcón, 
Isabel (coord.), El compromiso de Caspe (1412), cambios dinásticos y constitucionalismo en la Corona de Aragón, Zaragoza, Obra Social de Ibercaja, pp. 620-629.

Pichel, Antonio (1987), Ficción poética e vocabulario feudal na lírica trobadoresca galego-portuguesa, A Coruña, Diputación Provincial.

Reddy, William M. (2012), The Making of Romantic Love: Longing and Sexuality in Europe, South Asia \& Japan, 900-1200 CE, Chicago - Londres, The University of Chicago Press.

Riquer, Martí de (1964), Història de la literatura catalana. Part antiga, vol. I, Barcelona, Ariel.

Rodón Binué, Eulalia (1957), El lenguaje técnico del feudalismo en el siglo XI en Cataluña (contribución al estudio del latín medieval), Barcelona, Consejo Superior de Investigaciones Científicas, Escuela de Filología.

Roncaglia, Aurelio (1992), Guillaume IX d'Aquitaine et le jeu du trobar (avec un plaidoyer por la déidéologisation de Midons), dins Gouiran, Gérard (coord.), Contacts de langues, de civilisations et intertextualité. IIIème Congrès International de l'Association Internationale d'Études Occitanes, Montpeller, Centre d'Études Occitanes de l'Université de Montpellier, vol. III, pp. 1105-1117.

Sabaté, Flocel (1998), Ejes vertebradores de la oligarquía urbana en Cataluña, "Revista d'Història Medieval" 9, pp. 127-153.

Sabaté, Flocel (2009), Estamentos, soberanía y modelo político en la Cataluña bajomedieval, "Aragón en la Edad Media" 21, pp. 245-278.

Sabaté, Flocel (2013), Identitat i representativitat social a la Catalunya baixmedieval, dins Casals, Àngel (dir.), El Compromís de Casp: negociació o imposició?, Cabrera de Mar, Galerada, pp. 53-93.

Sánchez Trigo, Elena (1990), Formas de tratamiento otorgadas a la mujer por los trovadores provenzales, "Filología románica" 7, pp. 131-149.

Sutherland, Dorothy R. (1956), The Language of the Troubadours and the Problem of Origins, "French Studies" 10/3, pp. 199-215.

Tavani, Giuseppe (1980), Literatura i societat a Barcelona entre la fi del segle XIV i el començament del XV, dins Actes del col-loqui internacional de llengua i literatura catalanes (Andorra, 1-6 d'octubre de 1979), Barcelona, Publicacions de l'Abadia de Montserrat, pp. 7-40.

Terry, Arthur (2003), A Companion to Catalan Literature, Woodbridge, Tamesis.

Torró, Jaume (2009), Lluís de Requesens, Bernat Miquel, Martí Garcia, Rodrigo Dies, Lluís de Vila-rasa, Francesc Sunyer: Sis poetes del regnat d'Alfons el Magnànim, Barcelona, Barcino. 
Trésor de la Langue Française informatisé (TLFi) http://atilf.atilf.fr/ [consulta: 29/07/2014].

Valdeón, Julio; Salrach, José M.; Zabalo, Javier (1980), Historia de España, 4: Feudalismo y consolidación de los pueblos hispánicos (siglos XI$X V$ ), Barcelona, Labor.

Vicens i Vives, Jaume (1956), El segle XV: els Trastàmares, Barcelona, Vicens-Vives.

Vidal Alcover, Jaume (1980), Síntesi d'història de la literatura catalana, vol. I, Barcelona, La Magrana.

APÈNDIX: RELACIÓ DE POETES D’OBRA CONSULTADA

Anònim Florència ms. Palatino 1052 (1 poema)

Anònims Mahiques 2012 (4 poemes)

Joan Basset (20 poemes)

Pau de Bellviure (1 poema)

Joan Blanch (1 poema)

Jaume Bonet (2 poemes)

Cançoneret de Ripoll (20 poemes)

Joan de Castellnou (11 poemes)

Rodrigo Dies ( 3 poemes)

Jacme Escrivà (3 poemes)

Andreu Febrer (15 poemes)

Francesc Ferrer (10 poemes)

Joan Ramon Ferrer (2 poemes)

Gabriel Ferrús (6 poemes)

Figueres (4 poemes)

Joan Fogassot (10 poemes)

Martí Garcia (11 poemes)

Melcior de Gualbes (3 poemes)

Francí Guerau ( 7 poemes)

Lluís Icart (14 poemes)

Ivany ( 2 poemes)

Joseta (1 poema)

Romeu Llull (17 poemes)

Llorenç Mallol (2 poemes)

La reina de Mallorques (1 poema)

Arnau March (6 poemes)

Ausiàs March (128 poemes)

Jaume March (10 poemes) 
Pere March (11 poemes)

Pere Martines (4 poemes)

Guillem de Masdovelles (15 poemes)

Joan Berenguer de Masdovelles (180 poemes)

Pere Joan de Masdovelles (6 poemes)

Guerau de Massanet (1 poema)

Bernat Miquel ( 2 poemes)

A. de Muntanyans (1 poema)

Joan Olivella (1 poema)

Bernat de Palaol (2 poemes)

Aznar Pardo (2 poemes)

Tomàs Peris de Foces (2 poemes)

Pere Pou (1 poema)

Gilabert de Próixita (20 poemes)

Pere de Queralt (1 poema)

Rajadell (1 poema)

Lluís de Requesens (9 poemes)

Bernat Hug de Rocabertí ( 2 poemes)

Joan Roís de Corella (17 poemes)

Jaume Rovira (2 poemes)

Narcís de Sant Dionís (1 poema)

Jordi de Sant Jordi (16 poemes)

Bernat Serra (1 poema)

Joan Sesavasses (1 poema)

Blai Seselles (2 poemes)

Francesc Sunyer (5 poemes)

Pere Torroella (29 poemes)

Pere Tresfort ( 3 poemes)

Antoni Vallmanya (21 poemes)

Francesc de la Via (4 poemes)

Lluís de Vila-rasa (11 poemes)

Total: 688 poemes

Fecha de recepción del artículo: septiembre 2014

Fecha de aceptación y versión final: febrero 2015 